\title{
Literature translated from Dutch in the Czech publishing house Družstevní práce during the Nazi occupation
}

\section{WILKEN ENGELBRECHT}

DOI: https://doi.org/10.31577/WLS.2021.13.3.5

Družstevní práce (Cooperative Labour, hereafter DP) was among the most important Czech publishing houses. As it was a joint venture of readers, editors and publishers, it survived even after the communist law on the publishing and distribution of books liquidated most private publishers. ${ }^{1}$ Nevertheless, DP was gradually suppressed until the publishing concession was cancelled in 1952. Fortunately, a considerable part of its archive is preserved in the National Literary Archive in Prague (Literární archiv Památníku národního písemnictví, LA PNP). Among these are the minutes of DP's editorial board, plans, and correspondence with Czech authorities (Knap 1971, $2,197)$, giving us insight into discussions about foreign literary works proposed for publication. This article demonstrates how proposed translations from Dutch were treated by the board depending on the current political situation.

After a survey of DP's history and a sketch of the political situation in the 1930s and 1940s, a short survey of the development of Czech translations from Dutch will be provided. Dutch and Flemish literary works served as a literary "escape route" for publishers unwilling to publish Nazi-friendly literature during the World War II. Usually DP returned rejected materials to the writers or foreign publishers, but some complete translations are preserved in the archives, which were postponed for publication until after the liberation of Czechoslovakia or were never published at all. The attack on the Deputy Reich Protector Reinhard Heydrich in May 1942 and the consequent Nazi retaliation on the Czech population (the so-called Heydrichiade) were also a turning point for Czech translations of foreign literature.

\section{THE PUBLISHING HOUSE DRUŽSTEVNÍ PRÁCE}

The idea behind Družstevní práce was that books could be cheaper if financially supported jointly by readers, writers and designers. Members of DP were supposed to purchase at least four publications annually. Conversely, they had the right to propose book titles, to recommend illustrators, and to vote on books to be published. Prior to the occupation, DP had 25,000 members, their numbers increased to 45,000 during the war, and just before the closure of DP in 1951 there were 100,000 members. The general trend of the house was pacifistic and humanistic, with a left-wing tendency (Havel 1985). DP originally had two main series: the first, and largest, Živé knihy A (Living books A), was aimed at the average DP reader, being middle class 
people, offering both Czech and translated literary works, while the second, Živé knihy $\mathrm{B}$, aimed at more discerning readers.

Since the middle of the 19th century, it had become a Czech tradition that "high literature" was to be translated directly from the source language (Engelbrecht 2021, 47-52). This was the reason why, in the case of translations of Dutch-language literature, DP cooperated with specialised literary translators Lída Faltová (1890-1944) and Rudolf J. Vonka (1877-1964), both of whom had contacts with the Dutch literary scene.

\section{THE POLITICAL SITUATION AND CENSORSHIP}

After 1933, Czechoslovakia was gradually becoming an isolated island of democracy on the changing map of East Central Europe. With the Munich Agreement of 30 September 1938, Hitler annexed all its German-speaking peripheral regions and a fascist regime was installed in what remained of the country. A consequence of this was the establishment of a Central Censorship Commission (Ústřední cenzorní komise, ÚCK) subordinate to the Press Office of the Presidium of the Ministerial Council (tiskový odbor Předsednictva ministerské rady, TO PMR) and of a National Cultural Council. The latter declared a new cultural policy on 20 December 1938 in its manifesto $O$ novou národní kulturu (For a new national culture):

The blow dealt to our nation and state was caused both by political reasons and by the internal confusion in our spiritual life. [...] Let us cast out all creative destructiveness, moral coarseness, villainy, cowardice; let us also arouse in art a sense of honour, heroism, discipline and order. It was not our people who were defeated, but the erring ideas. The basis of all creative life must be sovereign values: fatherland, land, nation, God (Malý $1938,233){ }^{2}$

This practically meant elimination of such "erring ideas". When Slovakia declared its independence on 14 March 1939, Hitler occupied the remainder of the Czech Lands, turning them into the Protectorate of Bohemia and Moravia. In April 1939, the Association of Czech Booksellers and Publishers (Svaz českých knihkupců a nakladatelů) edited a list of 744 titles to be excluded from public libraries and bookshops (Poláček 2004, 78). This list was reworked several times until the final Liste des schädlichen und unerwünschten Schrifttums im Protektorat Böhmen und Mähren of 31 March 1944 comprised about 2,400 entries concerning some 10,000 titles (138-141). This was a Czech version of the German index published in 1935 that was regularly updated until 1943 (Sturge 2004, 28-29). Like the German index, the Czech one was also strictly confidential and for internal use by the censors.

In Bohemia, 1942 was a turning point. Initially, the Nazis believed that it would be enough to eliminate the left-wing elite and lead the population gently into submission. As resistance grew, in September 1941 Hitler appointed Reinhard Heydrich as Deputy Reich Protector to suppress disobedience. When Heydrich began to liquidate the Czech resistance, the government in exile decided to assassinate him. The attack took place on 27 May 1942 and the severely wounded Heydrich died several days later. The Nazis' retribution included the execution of 539 Czech intellectuals held as hostages. 
In 1942, responsibility for censorship was transferred to the Ministry of Public Information (Ministerstvo lidové osvěty, MLO), and it became harsher. ${ }^{3}$ The head of the ÚCK, ${ }^{4}$ August von Hoop (1899-1946), a German-speaking Czech who was before 1939 editor of the daily Prager Presse, ${ }^{5}$ tried to change the orientation of Czech publications towards "useful themes" like "the apotheosis of motherhood". It was also decreed that literature in translation, but not of German works, should be limited. Thus while the overall number of translations fell sharply, the share of translations from German increased to $70 \%$ in 1944 (Janáček 2015, 948-953). Of course, this had repercussions on the production of translations of Dutch-language literature. Several books for which royalties had already been paid or of which translations were ready, could not be published, officially due to a "paper shortage" or because preference was being given to translations from German. For instance, the non-fiction book Geheimen van ruimte en tijd (Secrets of space and time), by Herko Groot (1890-1974), for which permission was applied in October 1942, was not allowed with a delay of two years, the reason being: "The submission of non-German foreign-language literature is to be restricted significantly, taking into account the measures in paper management." 6

Towards 1945, the total number of publications decreased significantly. DP's archives contain the reports that had to be submitted to the MLO every half year, and as of June 1942, monthly. As the end of the war approached, its effect could be seen in the last brief report: "We did not publish a single book in the month of April 1945."

\section{DUTCH-LANGUAGE LITERATURE IN CZECH TRANSLATION}

Although Dutch is a rather peripheral language, its literature has been translated into many languages since the middle of the 19th century. Between 1846 and 1938, some 275 works were translated into Czech, including nearly all important titles of that period. From the Dutch point of view, these are rather large numbers, surpassing the number of Dutch books rendered into Hungarian (some 30 titles) and Polish (85). From the Czech point of view, however, Dutch was a niche literature: only some $0.65 \%$ of all translations in this period were from Dutch.

As nearly from all other source languages, Czech translations from Dutch began in the 1840s, in this case with the novels by Hendrik Conscience (1812-1883), the main author of the Flemish Movement struggling for equality with the French in Belgium. Since the Czechs had a similar language struggle with German-speakers, Conscience's social novels were of interest to them. At the fin de siècle, several writers such as Louis Couperus (1863-1923), the dramatist Herman Heijermans (1864-1924) and the anti-colonial writer Multatuli [Eduard Douwes Dekker] (1820-1887) received attention in serious periodicals. At the beginning of the 20th century, contemporary authors like the late Romantic Modernist Frederik van Eeden (1860-1932) and the internationally popular Flemish writer of regional novels Felix Timmermans (18861947) were translated. Czech publication trends generally followed the tendencies of the German book market. 
In the 1930s, when Faltová and Vonka began translating, direct connections between Czech publishers and their Dutch and Flemish counterparts were established. This resulted in a boom in translations from Dutch, which appeared in various literary series, like Rudolf Škeříks Symposium, the European book club (Evropský literární klub, ELK) of the liberal house Sfinx or DP’s Živé knihy. Czech writers and Dutch and Flemish authors began to meet each other through the PEN club. As rural literature was a popular Czech genre during the 1930s, works by Flemish writers such as Ernest Claes (1885-1968) and Timmermans or Dutch authors such as Antoon Coolen (1897-1961) were often translated and their work was discussed extensively by the theorist of rural literature, Antonín Matula (1885-1953), in his Hlasy zemé $v$ evropských literaturách (The voices of earth in European literatures, 1933). The literary agent Vincy Schwarz (1902-1942) negotiated most of the contracts for Dutch and Flemish works to be translated into Czech in the 1930s and 1940s. ${ }^{8}$

\section{DUTCH TRANSLATIONS DURING THE 1940s}

The average number of Dutch titles translated into Czech up until 1930 was about three per year. This number doubled in the 1930s, while 61 translations were published during the German occupation, two-thirds of them being new translations, followed by 42 translations (incl. eight reprints) in 1946-1948. This meant a significant increase to nearly nine translations per year during the occupation, ${ }^{9}$ and up to 14 per year in the three post-war years. This was due to the growing number of "enemy" languages banned by the Nazi regime: in September 1939, all British and French literature was forbidden except classics like Shakespeare, in July 1941 all Russian and Polish authors, and in December 1941 all American writers (Janáček 2015, 945). The literature of minor occupied nations, such as Belgian, Danish, Dutch, Norwegian, Serbian and Slovenian, was allowed. Translations from these languages filled in the gaps previously held by major languages in many series (Poláček 2004, 117). The Czech situation was similar to that in Germany (Sturge 2004, 62-66; Van Uffelen 1993, 275-276), which is no surprise as the Protectorate was treated as a more or less autonomous part of the Reich.

An increase in Dutch translated works was visible in all of the major publishing houses that offered such authors before the war: the liberal houses Albert, ELK and Sfinx, the literary series Symposium, the Catholic house Vyšehrad, the social-democrat Melantrich and the cooperative DP. Due to its middle-class orientation, DP had authors cherished by Dutch and Flemish readers: in addition to Multatuli, they included the popular Flemish writer Felix Timmermans, the Dutch historical novelist Johan Fabricius (1899-1981), and the Dutch novelist and journalist Madelon Lulofs (18991958), who criticized the colonial system in the Dutch East Indies. Before the war, Timmermans, Fabricius and Lulofs were quite popular with Czech readers as well.

\section{DRUŽSTEVNÍ PRÁCE AND DUTCH AND FLEMISH LITERATURE DURING THE OCCUPATION}

After 1939, an increasing number of Dutch-language works were mentioned in the minutes of DP's editorial board, culminating in April 1942, when such works were one-third of all books discussed. The others were mostly works by Scandina- 
vian authors or original Czech literature. In those years, DP published seven novels of Dutch or Flemish origin (Appendix I, A). The two which came out in 1939 were planned before the occupation, all titles published in 1940 and 1941 were reprints of pre-war publications, and just the Czech edition of De Vlaschaard (The Flaxfield) by Stijn Streuvels (1871-1969) was a new one. Eight prepared titles were forbidden (Appendix I, B) and six works were discussed but not translated during the occupation (Appendix I, C).

That Streuvels's novel was published is no coincidence. As Kate Sturge (2004, $63,110)$ remarks, Flemish rural literature was officially favoured because it was a politically "kindred" literature, and Streuvels was one of two favorites, the other being Timmermans. They were ideologically interpreted as representatives of Blut-und-Boden-Literatur. Both received the Nazi Rembrandt-Preis, Streuvels in 1936 and Timmermans in $1942 .{ }^{10}$ Their work, however, did not really propagate Nazi ideology, and, from a Czech point of view, it was important that Streuvels was among the few writers who participated in the 1938 PEN congress in Prague, explicitly supporting the Czech case (Engelbrecht 2021, 203-205). Thus, his novel was acceptable from an anti-Nazi view as well.

The re-edition of Fabricius's De scheepsjongens van Bontekoe (The cabin boys of Bontekoe) was allowed because the novel was seen as youth literature. Nevertheless, Fabricius, an outspoken anti-Nazi, fled to England in 1940, where he became one of the voices of the Free Dutch radio aimed at the occupied Netherlands. This fact must have become clear to the ÚCK, and DP's request for permission of a third edition of his successful novel De leeuwen hongeren in Napels (The lions starve in Naples) was rejected without mentioning a reason.

The editorial board discussed 24 works in Dutch between April 1939 and April 1942 (Appendix II) but after May 1942, the ÚCK restricted all translations other than those from German, and no further Dutch-language work was mentioned. This was due to the Heydrichiade, the Nazi retaliations for the attack on Heydrich, in which many Czech intellectuals became victims of Nazi atrocities. Among them was the main literary agent Vincy Schwarz, whom the Gestapo had arrested in March 1942, and was executed by a firing squad on 30 June 1942. Schwarz's archives, containing agreements and correspondence with dozens of authors from about 40 countries, were seized by the Gestapo and have never been found (Václavek 1966, 8).

The minutes of the editorial board after 1942 limit themselves mostly to decisions. For this reason, it is not impossible that Dutch-language literature was discussed, but this fact was not registered in the minutes. The works discussed during the said period were similar to those during the interwar period. The main portion consisted of books by middlebrow authors like Fabricius, several of whose novels already published before the war were suggested for republication, and Godfried Bomans, a Catholic writer of humorous works (1913-1971), whose 1941 novel Eric of het klein insectenboek (Eric in the land of the insects) was proposed for translation. Faltová signed a translator's contract but due to her deteriorating health was not able to translate it; she died on 8 December 1944. 
Before the war, DP published several left-wing writers, including the Socialist Jef Last (1898-1972) and the Flemish journalist Lode Zielens (1901-1944), a writer of social realist novels. ${ }^{11}$ Regarding the latter, in 1937 DP had acquired the rights to his popular 1932 novel Moeder, waarom leven wij? (Mother, why do we live?), a Marxist-leaning work about a worker's family in Antwerp. The house planned to publish it in autumn 1939, but, after the occupation, it was clear that the book would have no chance of getting the permission of the UCK. Thus, DP postponed publication, but the novel was even not published after the war. Interestingly, DP tried to publish the novel Stiefmoeder Aarde (Stepmother Earth) by the communist Dutch writer Theun de Vries (1907-2005). Faltová corresponded in July 1937 on behalf of DP with his publisher Van Loghum Slaterus, and an agreement was signed in October 1937. The translation was ready in June 1939 but the publication planned for November 1939 was stopped by DP's directors due to the fact that Bohemia was already under German occupation. The editors were requested to reconsider whether the novel's publication would be convenient, as it was a rural novel about the Frisian countryside, but the author was left-leaning. ${ }^{12}$ For this reason, board member Vladimír Procházka (1895-1968) promised in December 1940 to assess the "suitability" of the book. ${ }^{13}$ His report must have been negative, as DP communicated on 15 October 1942 to Van Loghum Slaterus: "The Czech edition of your work by Theun de Vries, 'Stiefmoeder Aarde' has not yet been realized because of obstacles that are not under our control. We have this matter on record and will notify you as soon as we can continue with the same."14

Exactly half of the works discussed belonged to the regional genre and most of the authors were Catholic. In the interwar period, DP considered such writers less useful for its mostly left-wing readers. Thus, rural novels were often published by the liberal house Sfinx and its partner ELK: the Flemish writers Ernest Claes, Valère Depauw (1912-1994), Streuvels and Gerard Walschap (1898-1989) and the Dutch Coolen. Felix Timmermans, the most important Flemish regional author, was, however, a "DP author". It can be seen from the minutes of the editorial board that DP tried to take over promising rural authors from competing publishers during the war.

In June 1940, the board discussed the possibility of publishing a new edition of Timmerman's Boerenpsalm (Farmer's psalm), his only major work being not in DP collections. This did not work out and, moreover, two other works by Timmermans were published in 1942 and 1943 by Škerrík. ${ }^{15}$ In the case of Streuvels and Walschap, DP succeeded. The fact that the board was aware of encroaching on the domain of Sfinx is clear from the discussion in the board meeting of 3 December 1941, when the secretary Vojtěch Hanč (1906-1997) remarked that Sfinx/ELK had an option on Walschap's oeuvre. DP succeeded in the acquisition of two novels by Walschap, the children's story De vierde koning (The fourth king) and his novel Adelaïde. Due to wartime conditions, however, neither was published. Of the first book, a complete translation is present in the archive but DP did not try to gain the permission of the MLO, and Adelaïde came out in 1947 from another publisher. 
The UCK recommended to publish more non-fiction. This is reflected in the minutes. In the case of "a colonial novel by Multatuli" (his Max Havelaar, published in 1947 in a translation by Vonka), Rumeiland (Rum island) by the very productive and prolific author Simon Vestdijk (1898-1971) and Streuvels' Prutske, the board recalled that too many novels had been accepted. In order to have more non-fiction books, the board recommended the books Vangen en jagen in Sumatra's wildernis (Catch and hunt in Sumatra's wilderness) by Abraham C. van der Valk (1898-after 1939), and Groot's Geheimen van ruimte en tijd (Secrets of space and time). Both were translated, publication permission was requested but not obtained.

Due to wartime circumstances and the growing number of unpermitted books, DP's economic situation became precarious. This was often explicitly mentioned in 1943 and 1944 by DP's directors in requests for publication permission. Nevertheless, DP tried to maintain its standards. Thus, the novel De vos en zijn staart (The fox and his tail) by the Dutch novelist Cees Kelk (1901-1981), De afrekening (The settlement) by the Flemish Catholic regional author André Demedts (1906-1992), and Streuvels' Prutske were rejected as not interesting enough. Flemish writers openly collaborating with the Nazis, such as Cyriel Verschaeve (1874-1949), Filip De Pillecyn (18911962), and Ferdinand Vercnocke (1906-1989), were never translated into Czech.

\section{CONCLUSION}

After the war, DP could proudly state that it did not publish any Nazi work during the occupation (Cerman 1945, 109; Havel 1985, 604). Just as Catholic publishers had acted in Germany (van Uffelen 1993, 260-261), DP used the position of Flemish regional authors as a "kindred" literature to fill the gaps in its book series caused by the bans on "enemy" literatures. Their works were acceptable, yet it was not Nazi literature.

The fact that the index of banned works was confidential caused uncertainty as which authors were allowed and which banned, and as in Germany, this led to self-censorship. A clear example was De vierde koning by Walschap. Notwithstanding the fact that royalties were paid, the translation was made and the publication planned, DP decided not to ask for publication permission.

In the end, just one of the ten books recommended by DP's editorial board and accepted by the directors for publication - Lništé, the translation of De Vlaschaard by the popular Flemish author and Belgian PEN member Streuvels - was among the seven books published by DP during the war, while several planned and translated works were published after the liberation, either by DP or by other publishers.

\section{ARCHIVAL FONDS}

Literární archiv Památníku národního písemnictví, Prague, Fond 70/57, Družstevní práce. Letterenmuseum, The Hague, fund Van Loghem Slaterus/Družstevní práce. 


\section{Appendix I -Translations of Dutch literature planned by DP during World War II}

\section{A. Published books}

\begin{tabular}{|c|c|c|c|}
\hline Year & $\begin{array}{l}\text { Writer } \\
\text { (Translator) }\end{array}$ & $\begin{array}{l}\text { Original Title } \\
\text { (Czech Title) }\end{array}$ & Remarks \\
\hline 1939 & $\begin{array}{l}\text { Nienke van } \\
\text { Hichtum } \\
\text { (Lída Faltová) }\end{array}$ & $\begin{array}{l}\text { Oehoehoe } \\
\text { (Uhuhu) }\end{array}$ & $\begin{array}{l}\text { writer's agreement 11-11-1937; } \\
\text { translation agreement 18-2- } \\
\text { 1938; 4-6-1939 print; 3,300 } \\
\text { copies }\end{array}$ \\
\hline 1939 & $\begin{array}{l}\text { Madelon Lulofs } \\
\text { (Lída Faltová) }\end{array}$ & $\begin{array}{l}\text { De hongertocht } \\
\text { (Hladová výprava) }\end{array}$ & $\begin{array}{l}\text { agreement } 1936 \text {, translated } \\
1939 ; 7,700 \text { copies }\end{array}$ \\
\hline 1940 & $\begin{array}{l}\text { Johan Fabricius } \\
\text { (Lída Faltová) }\end{array}$ & $\begin{array}{l}\text { De scheepsjongens van } \\
\text { Bontekoe } \\
\text { (Plavčíci kapitána Bonte- } \\
\text { koea) }\end{array}$ & $\begin{array}{l}\text { 2nd edition; request to TO } \\
\text { PMR 30-10-1940; permission } \\
\text { 4-8-1941; 3,300 copies }\end{array}$ \\
\hline 1940 & $\begin{array}{l}\text { Felix Timmer- } \\
\text { mans } \\
\text { (Rudolf Vonka) }\end{array}$ & $\begin{array}{l}\text { Pallieter } \\
\text { (Pallieter) }\end{array}$ & 2nd edition; 4,400 copies \\
\hline 1940 & $\begin{array}{l}\text { Felix Timmer- } \\
\text { mans } \\
\text { (Rudolf Vonka) }\end{array}$ & $\begin{array}{l}\text { Pieter Breughel } \\
\text { (Petr Breugel) }\end{array}$ & 2nd edition; 4,400 copies \\
\hline 1941 & $\begin{array}{l}\text { Johan Fabricius } \\
\text { (Lída Faltová) }\end{array}$ & $\begin{array}{l}\text { Trilogie. I. De komedian- } \\
\text { ten trokken voorbij. II. } \\
\text { Melodie der verten. III. De } \\
\text { dans rond de galg } \\
\text { (Trilogie. I. Jeli tudy kome- } \\
\text { dianti. II. Melodie dálek. } \\
\text { III. Tanec kolem šibenice) }\end{array}$ & $\begin{array}{l}\text { 2nd edition; request to TO } \\
\text { PMR 8-6-1940; agreement } \\
\text { revision 21-4-1941; permission } \\
\text { 4-8-1941; 7,700 copies }\end{array}$ \\
\hline 1942 & $\begin{array}{l}\text { Stijn Streuvels } \\
\text { (Lída Faltová) }\end{array}$ & $\begin{array}{l}\text { De Vlaschaard } \\
\text { (Lniště) }\end{array}$ & $\begin{array}{l}\text { agreement } 30-1-1941 \text {; per- } \\
\text { mission TO PMR 18-6-1941; } \\
\text { permission MLO 28-2-1942 }{ }^{16} \text {; } \\
\text { permission MLO 10-6-1942; } \\
8,800 \text { copies }\end{array}$ \\
\hline
\end{tabular}


B. Books prepared but not published

\begin{tabular}{|c|c|c|c|}
\hline Year & $\begin{array}{l}\text { Writer } \\
\text { (Translator) }\end{array}$ & $\begin{array}{l}\text { Original Title } \\
\text { (Czech Title) }\end{array}$ & Remarks \\
\hline 1939 & $\begin{array}{l}\text { Lode Zielens } \\
\text { (Lída Faltová) }\end{array}$ & $\begin{array}{l}\text { Moeder, waarom leven } \\
\text { wij? } \\
\text { (Matko, proč žijeme?) }\end{array}$ & $\begin{array}{l}\text { agreement 3-7-1935; royalties } 15- \\
3-1937 \text {; translated 1937; planned } \\
\text { for autumn } 1939\end{array}$ \\
\hline 1939 & $\begin{array}{l}\text { Theun de Vries } \\
\text { (Lída Faltová) }\end{array}$ & $\begin{array}{l}\text { Stiefmoeder Aarde } \\
\text { (Macecha země) }\end{array}$ & $\begin{array}{l}\text { 30-6-1937 readers' reviews; } \\
\text { 6-7-1937 letter to Van Loghum } \\
\text { Slaterus; 14-9-1937 translation } \\
\text { agreement; 1-10-1937 agreement; } \\
\text { translation ready June 1939; } \\
\text { publication planned Nov. 1939; } \\
\text { 11-12-1940 new review; 15-10- } \\
\text { 1942 edition not yet possible }\end{array}$ \\
\hline 1941 & $\begin{array}{l}\text { Gerard } \\
\text { Walschap } \\
\text { (Lída Faltová) }\end{array}$ & $\begin{array}{l}\text { De vierde koning } \\
\text { (Čtvrtý král) }\end{array}$ & $\begin{array}{l}\text { 21-5-1941 recommendation; } \\
\text { readers' reviews Nov. 1941; } \\
\text { translation ready } 1942\end{array}$ \\
\hline 1942 & $\begin{array}{l}\text { Johan Fabricius } \\
\text { (Lída Faltová) }\end{array}$ & $\begin{array}{l}\text { Leeuwen hongeren in } \\
\text { Napels } \\
\text { (Lvi hladovějí v Neapoli) }\end{array}$ & $\begin{array}{l}\text { 3rd edition; request to MLO } 21 \text { - } \\
\text { 2-1942; MLO 31-7-1942 rejected } \\
\text { (no reason) }\end{array}$ \\
\hline 1942 & $\begin{array}{l}\text { A.C. van der } \\
\text { Valk } \\
\text { (Rudolf Vonka) }\end{array}$ & $\begin{array}{l}\text { Vangen en jagen in de } \\
\text { wildernis van Sumatra } \\
\text { (Lov a honby na Sumatře } \\
\text { v divočině) }\end{array}$ & $\begin{array}{l}\text { request to MLO 19-3-1942; } \\
\text { repeated request 1-5-1942 }\end{array}$ \\
\hline 1943 & $\begin{array}{l}\text { Jo van Ammers- } \\
\text { Küller }\end{array}$ & $\begin{array}{l}\text { De opstandigen } \\
\text { (Povstalkyně) } \\
\text { De vrouwenkruistocht } \\
\text { (Křižácké tažení) }\end{array}$ & $\begin{array}{l}\text { Both novels were supposed to } \\
\text { be published by the Legionary } \\
\text { House Čin in } 1943 .{ }^{17}\end{array}$ \\
\hline 1944 & $\begin{array}{l}\text { Herko Groot } \\
\text { (Rudolf Vonka) }\end{array}$ & $\begin{array}{l}\text { Geheimen van ruimte en } \\
\text { tijd } \\
\text { (Záhady prostoru a času) }\end{array}$ & $\begin{array}{l}\text { reader's report 8-4-1942; } \\
\text { agreement with Meulenhoff 5-6- } \\
\text { 1942; request to MLO 2-11-1942; } \\
\text { prohibited by MLO 3-6-1944 } \\
\text { (paper shortage) }\end{array}$ \\
\hline
\end{tabular}




\section{Titles reviewed and discussed but not translated during the World War II}

\begin{tabular}{|c|c|c|c|}
\hline Year & $\begin{array}{l}\text { Writer } \\
\text { (Translator) }\end{array}$ & $\begin{array}{l}\text { Original Title } \\
\text { (Czech Title) }\end{array}$ & Remarks \\
\hline 1941 & $\begin{array}{l}\text { Arthur van } \\
\text { Schendel } \\
\text { (Lída Faltová) }\end{array}$ & $\begin{array}{l}\text { Het fregatschip Johanna } \\
\text { Maria } \\
\text { (Plachetnice Johana } \\
\text { Maria) } \\
\text { De waterman (Vodák) }\end{array}$ & $\begin{array}{l}\text { 15-10-1941 proposed by Jan Mil; } \\
\text { 16-12-1941 readers' reviews }\end{array}$ \\
\hline 1942 & $\begin{array}{l}\text { Ferdinand } \\
\text { Bordewijk } \\
\text { (Rudolf } \\
\text { Vonka) } \\
\text { Gerard } \\
\text { Walschap } \\
\text { (Lída Faltová?) }\end{array}$ & $\begin{array}{l}\text { Apollyon } \\
\text { (Appollyon) } \\
\text { Adelaïde }\end{array}$ & $\begin{array}{l}\text { 30-6-1942 reader's review } \\
\text { 3-12-1941 discussed, fate uncertain }{ }^{18}\end{array}$ \\
\hline 1943 & $\begin{array}{l}\text { Simon Vestdijk } \\
\text { (Lída Faltová) }\end{array}$ & Rumeiland & $\begin{array}{l}\text { 11-2-1942 book discussed; } 24-6- \\
1942 \text { royalties agreement; } 23-7-1943 \\
\text { final agreement }\end{array}$ \\
\hline 1944 & $\begin{array}{l}\text { Godfried } \\
\text { Bomans } \\
\text { (Lída Faltová) } \\
\text { (Ella Kazdová) }\end{array}$ & $\begin{array}{l}\text { Eric of het klein } \\
\text { insectenboek } \\
\text { (Erik aneb kniha o } \\
\text { hmyzu) }\end{array}$ & $\begin{array}{l}\text { request to TO PMR 5-1-1942; } \\
\text { 27-11-1942 Bomans sends a new } \\
\text { preface for the translation; June } \\
1943 \text { two reviews; } 21-2-1944 \\
\text { translation agreement with Faltová; } \\
\text { 9-11-1947 translation agreement } \\
\text { with Kazdová; } 1948 \text { ready }\end{array}$ \\
\hline
\end{tabular}

\section{Appendix II - Works discussed by the DP editorial board 1939-1945}

\begin{tabular}{|l|l|l|}
\hline Date & $\begin{array}{l}\text { Work and author } \\
\text { discussed }\end{array}$ & Decision \\
\hline $\begin{array}{l}06 / 04 \\
1939\end{array}$ & $\begin{array}{l}\text { Charles De Coster, } \\
\text { Uhlenspiegel }\end{array}$ & Proposed by Vančura. Original work required. \\
\hline $\begin{array}{l}13 / 04 \\
1939\end{array}$ & $\begin{array}{l}\text { Charles De Coster, } \\
\text { Vlámské legendy }\end{array}$ & To be read by Šnobr. \\
\hline $\begin{array}{l}27 / 04 \\
1939\end{array}$ & Charles De Coster, & $\begin{array}{l}\text { Šnobr read the German translation. The book is } \\
\text { appropriate for translation. }\end{array}$ \\
\hline $\begin{array}{l}23 / 06 \\
1939\end{array}$ & Charles De Coster, & Original to be requested from France. \\
\hline $\begin{array}{l}06 / 10 \\
1939\end{array}$ & E. Claes, Kiki & $\begin{array}{l}\text { Proposed by Kostýřrová. Further information will } \\
\text { be asked for. }\end{array}$ \\
\hline $\begin{array}{l}20 / 12 \\
1939\end{array}$ & Huizinga, Le déclin du & $\begin{array}{l}\text { Proposed by Charvát in a new series of historical } \\
\text { monographs. }\end{array}$ \\
\hline
\end{tabular}




\begin{tabular}{|c|c|c|}
\hline $\begin{array}{l}10 / 01 \\
1940\end{array}$ & $\begin{array}{l}\text { Huizinga, Le déclin du } \\
\text { Moyen Âge }\end{array}$ & The director has given consent. \\
\hline $\begin{array}{l}14 / 02 \\
1940\end{array}$ & $\begin{array}{l}\text { Huizinga, Le déclin du } \\
\text { Moyen Âge }\end{array}$ & $\begin{array}{l}\text { Due to circumstances, the series will be } \\
\text { postponed. }\end{array}$ \\
\hline $\begin{array}{l}12 / 06 \\
1940\end{array}$ & $\begin{array}{l}\text { F. Timmermans, Selský } \\
\text { žalm }\end{array}$ & $\begin{array}{l}\text { Proposed by Vonka. The book is out of print at } \\
\text { Skeŕík, recommended. }\end{array}$ \\
\hline $\begin{array}{l}09 / 10 \\
1940\end{array}$ & $\begin{array}{l}\text { Van Wijk, Hlavní postavy } \\
\text { ruské literatury do světové } \\
\text { války }\end{array}$ & $\begin{array}{l}\text { Recommended by Vonka. The board is not } \\
\text { interested. }\end{array}$ \\
\hline $\begin{array}{l}11 / 12 \\
1940\end{array}$ & $\begin{array}{l}\text { Stijn Streuvels, De } \\
\text { vlaschaard } \\
\text { Theun de Vries, Macocha } \\
\text { země }\end{array}$ & $\begin{array}{l}\text { Procházka. Discussed among } 5 \text { "Nordic" novels. } \\
\text { Procházka will review this novel, considering } \\
\text { "present suitability". }\end{array}$ \\
\hline $\begin{array}{l}14 / 05 \\
1941\end{array}$ & $\begin{array}{l}\text { Gerard Walschap, De } \\
\text { vierde koning } \\
\text { A.C. van der Valk, Vangen } \\
\text { en jagen in Sumatra's } \\
\text { Wildernis }\end{array}$ & Both books recommended in Faltovás reviews. \\
\hline $\begin{array}{l}10 / 09 \\
1941\end{array}$ & $\begin{array}{l}\text { C.J. Kelk, De Vos en zijn } \\
\text { staart }\end{array}$ & $\begin{array}{l}\text { Recommended by Schwarz. Positive review by } \\
\text { Faltová; rejected after reading. Published in } 1946 \\
\text { in Faltovás translation by Chvojka in Prague. }{ }^{19}\end{array}$ \\
\hline $\begin{array}{l}24 / 09 \\
1941\end{array}$ & $\begin{array}{l}\text { H. Teirlinck, Maria } \\
\text { Speermaliová }\end{array}$ & $\begin{array}{l}\text { Proposed by Faltová. Recommended for } \\
\text { publication by the board. }{ }^{20}\end{array}$ \\
\hline $\begin{array}{l}05 / 11 \\
1941\end{array}$ & $\begin{array}{l}\text { Godfried Bomans, Erik } \\
\text { nebo malá kniha o } \\
\text { hmyzech }\end{array}$ & Proposed by Faltová, recommended by the board. \\
\hline $\begin{array}{l}12 / 11 \\
1941\end{array}$ & $\begin{array}{l}\text { Bomans, Erik } \\
\text { Arthur van Schendel, } \\
\text { Fregata Johana Maria; } \\
\text { Vodák }\end{array}$ & $\begin{array}{l}\text { Among } 3 \text { books accepted for publication. } \\
\text { Proposed by a DP member. Reviewed by Faltová. } \\
\text { Recommended for publication. }\end{array}$ \\
\hline $\begin{array}{l}26 / 11 \\
1941\end{array}$ & $\begin{array}{l}\text { Arthur van Schendel, } \\
\text { Fregata Johana Maria; } \\
\text { Vodák }\end{array}$ & Both accepted for publication. \\
\hline $\begin{array}{l}3 / 12 \\
1941\end{array}$ & $\begin{array}{l}\text { G. Walschap, Adelaïde } \\
\text { Demedts, Abrechnung }\end{array}$ & $\begin{array}{l}\text { Procházka remarks that the book has a high } \\
\text { literary quality. Secretary Hanč believes that Sfinx } \\
\text { has an option. Will be checked. } \\
\text { Procházka has read the book. The first two thirds } \\
\text { are good, the last part not. Rejected. }\end{array}$ \\
\hline $\begin{array}{l}07 / 01 \\
1942\end{array}$ & Strevels Stijn, Prutske & $\begin{array}{l}\text { Kakos remarks that it is an interesting book, well } \\
\text { written, but it does not fit into any series. He will } \\
\text { give the book to his family to read. }\end{array}$ \\
\hline $\begin{array}{l}04 / 02 \\
1942\end{array}$ & Streuwels, Prütske & $\begin{array}{l}\text { Kakos' wife has found the beginning of the book } \\
\text { beautiful, but not the latter part. The narration is } \\
\text { too protracted for DP readers. }\end{array}$ \\
\hline
\end{tabular}




\begin{tabular}{|c|c|c|}
\hline $\begin{array}{l}28 / 01 \\
1942\end{array}$ & $\begin{array}{l}\text { Colonial novel by } \\
\text { Multatuli } \\
\text { Eeden, Radostný svět }\end{array}$ & $\begin{array}{l}\text { Both proposed by DP member Vodrážka, not } \\
\text { accepted, because of the number of books } \\
\text { permitted to be published. }\end{array}$ \\
\hline $\begin{array}{l}11 / 02 \\
1942\end{array}$ & $\begin{array}{l}\text { Simon Vestdijk, } \\
\text { Rumeiland }\end{array}$ & $\begin{array}{l}\text { Engaging book. Kakos gives the reminder that too } \\
\text { many novels have been accepted, asks whether } \\
\text { the book in its category is unique. Procházka: } \\
\text { very interesting exotic novel. Recommended for } \\
\text { publication. }\end{array}$ \\
\hline $\begin{array}{l}25 / 02 \\
1942\end{array}$ & $\begin{array}{l}\text { Simon Vestdijk, } \\
\text { Rumeiland }\end{array}$ & The directors decide to publish the novel. \\
\hline $\begin{array}{l}01 / 04 \\
1942\end{array}$ & $\begin{array}{l}\text { Stijn Streuvels, Prutske } \\
\text { Herman Teirlinck, De } \\
\text { nieuwe Uilenspiegel } \\
\text { Herman Teirlinck, Het } \\
\text { ivoren aapje } \\
\text { Dr H. Groot, Geheimen } \\
\text { van ruimte en tijd }\end{array}$ & $\begin{array}{l}\text { Procházka has read the book and recommends it. } \\
\text { Enthusiastic review by Faltová. } \\
\text { Good review by Faltová. } \\
\text { After discussion, the board decides to recommend } \\
\text { Nový Uilenspiegel. } \\
\text { Good reviews by Faltová and Vonka. Nebesář will } \\
\text { ask Bělehrádek for a review. }\end{array}$ \\
\hline $\begin{array}{l}15 / 04 \\
1942\end{array}$ & $\begin{array}{l}\text { Dr H. Groot, Geheimen } \\
\text { van ruimte en tijd }\end{array}$ & $\begin{array}{l}\text { Bělehrádek wrote a positive review. The book is } \\
\text { recommended for publication. }\end{array}$ \\
\hline $\begin{array}{l}22 / 04 \\
1942\end{array}$ & $\begin{array}{l}\text { Dr H. Groot, Geheimen } \\
\text { van ruimte en tijd }\end{array}$ & The directors decide to publish the book. ${ }^{21,22}$ \\
\hline
\end{tabular}

\section{NOTES}

1 Zákon o vydávání a rozšiřování knih, hudebnin a jiných neperiodických publikací, č. 94/1949 Sb., https://www. zakonyprolidi.cz/cs/1949-94.

2 "Rána, která stihla náš národ a stát, byla způsobena jako příčinami politickými, tak i vnitřním zmatkem v životě duchovním. [...] Vymítejme ze vší tvorby rozkladnost, mravní otrlost, nízkost, zbabělost; ved’me i v umění $\mathrm{k}$ smyslu pro čest, hrdinnost, kázeň, řád. Nebyl poražen národ, ale bludné ideje. Základem všeho tvořivého života bud’ též svrchované hodnoty: vlast, země, národ, Bůh." All translations below are by the present author.

3 A similar shift took place in the Reich in 1938 where the responsibility for the index of forbidden books was transferred from the Reichsschrifttumskammer to the Propaganda Ministry (Sturge 2004, 28-29).

4 As of 1942, Ministerium für Volksaufklärung - Sektion Schrifttum.

5 The Prager Presse was founded in 1921 as a pro-Czechoslovak German daily. Von Hoop was its editor from 1926 until 1939. In April 1939, he joined the NSDAP and became main press censor. In September 1940, he replaced the former head of the ÚCK.

6 Bilingual in the original text: "Das Vorlegen der nichtdeutschen fremdsprachlichen Literatur ist mit Rücksicht auf die Massnahmen in der Papierbewirtschaftung wesentlich einzuschränken. / Předkládání neněmecké cizojazyčné literatury jest $s$ ohledem na směrnice pro obhospodařování papírem podstatně omeziti." (LA PNP, fond 70/57, 220/13 Korespondence DP s ostatními úřady 1939-1945; letter of 3 June 1944).

7 "V měsíci dubnu 1945 jsme nevydali žádnou knihu." (LA PNP, fond 70/57, 220/13 Korespondence DP s ostatními úradady 1939-1945; letter of 27 April 1945, no. 40137). 
8 Schwarz was an employee of the agency Centrum from 1933 to 1936, moved to Universum in 1936 and founded his own agency in 1937. In all cases, he signed the royalty agreements with Dutch publishing houses.

9 With only a few books published in the period between 1943 and 1945, the average from 1939 to 1942 was 13 books per year. The total number of translations of Dutch-written works in Germany in the same period was 174 titles, i.e. 43.5 per year (Sturge 2004, 60).

${ }^{10}$ Herbert van Uffelen (1993) devotes a major section to Streuvels' double position as a Blut-und-Boden writer and as a, less preferred, Catholic writer (263-276). He warns (262-263) that the popularity of Flemish writers should not only be ascribed to an interpretation as Blut-und-Boden literature.

${ }^{11}$ Last was one of the five authors of Dutch or Flemish origin indexed in the Liste des schädlichen und unerwünschten Schrifttums $(1944,124)$. The others were the anarchist Ferdinand Domela Nieuwenhuis (1846-1919), the Calvinist writer Johannes de Heer (1866-1961), the Belgian socialist politician Hendrik de Man (1885-1953), and the pacifist painter and writer Frans Masereel (1889-1972), whose works were burnt in Nuremberg in 1933 (Liste 1944, 53, 79, 132 and 135).

${ }^{12}$ It is clear that nobody at DP knew that De Vries joined the Communist Party in 1936.

${ }^{13}$ Vladimír Procházka joined the Communist Party in 1924 and was foreign correspondent for TASS. He was a literary translator of English prose. After the World War II, he was a Communist MP and one of the authors of the 1948 Communist constitution (Strohsová 2000).

14 "Die tschechische Ausgabe Ihres Verlagswerkes von Theun de Vries 'Stiefmoeder Aarde' könnten wir bisher, wegen an unserem Willen nicht abhängigen Hindernissen, nicht verwirklichen. Wir haben diese Angelegenheit stets in Evidenz und werden Sie gleich benachrichtigen, sobald wir in derselben fortsetzen werden können." (VLS/Družstevní práce, no. 1078/76, Letterenmuseum, The Hague).

${ }^{15}$ De harp van St. Franciscus (St. Francis' harp), translated by Jaroslav Toman as Prostáček Boží, and his new novel De familie Hernat (The Hernat family), translated as Rodinná kronika by Vonka, both for Škeř́k.

${ }^{16}$ This permission concerned the dust jacket.

${ }^{17}$ In the archive, a complete post-war translation (1946) of De vrouwenkruistocht by Marie Polívková -Jensen (1902-1989) is present, as well as an agreement signed on 22 January 1946. The rights were acquired from Čin which was closed in 1942. The first part was published in 1947 by the publishing house Za svobodu (For Freedom), Čin's post-war successor.

${ }_{18}$ The novel was published by the small press Varhaníková in Prague.

${ }^{19}$ As Faltová died on 8 December 1944, this means that the translation was finished earlier. The publisher Chvojka started after the liberation, and presumably took over this translation from DP.

${ }^{20}$ As the novel was published in 1947 by DP in Faltovás translation, it must have been commissioned to her in 1941 or 1942.

${ }^{21}$ In 1942, the editorial board had 13 other meetings. The board met 19 times in 1943, 22 times in 1944 and twice in 1945 before the liberation. In those years, practically only Czech books were discussed due to instructions from the Ministry of Public Information.

${ }^{22}$ In the tables the author followed the spelling of the names and titles in the archival material (with minor editorial changes).

\section{LITERATURE}

Cerman, Josef. 1945. "Dění v DP za války." Panorama 21, 1: 22-23; 2: 64-66; 3: 88-89; 4: 107-109.

Engelbrecht, Wilken. 2021. Van Siska van Rosemael tot Max Havelaar. Nederlandstalige literatuur in Tsjechische vertaling tussen 1848 en 1948. Gent: Academia Press.

Havel, Rudolf. 1985. "Družstevní práce." In Lexikon české literatury. Osobnosti, díla, instituce 1 (A-G), ed. by Vladimír Forst, 603-606. Prague: Academia.

Janáček, Pavel. 2015. "V zájmu národa. Literární cenzura v období krize liberalismu a eroze modernity." In V obecném zájmu. Cenzura a sociální regulace literatury v moderní české kultuře 1749-2014. II. 1949-2014, ed. by Michael Wögerbauer, Petr Píša, and Pavel Janáček, 883-1007. Prague: Academia. 
Knap, Josef. 1971. Družstevní práce. Soupis nakladatelského fondu. Prague: LA PNP (typoscript).

Liste des schädlichen und unerwünschten Schrifttums im Protektorat Böhmen und Mähren (Stand vom

31. März 1944).1944. (s.l. = Prague): Ministerium für Volksaufklärung.

Malý, Rudolf I. 1938. “O novou národní kulturu." Tak. Čtrnáctideník kulturní i politický 2, 16 (20 December): 233-236.

Matula, Antonín. 1933. Hlasy země v evropských literaturách. Praha: Svobodné učení selské.

Poláček, Václav. 2004. Kniha a národ 1939-1945. Rekonstrukce nevydaného pamětního sborníku Svazu českých knihkupců a nakladateli̊ z roku 1947. Ed. by Aleš Zach. Prague: Paseka.

Strohsová, Eva. 2000. "Vladimír Procházka." In Lexikon české literatury. Osobnosti, díla, instituce 3/II $(P-\check{R})$, ed. by Jiří Opelík. 1104-1106. Prague: Academia.

Sturge, Kate. 2004. "The Alien Within”: Translation into German during the Nazi Regime. Munich: Iudicium.

Uffelen, Herbert van, 1993. Moderne niederländische Literatur in deutscher Übersetzung, 1830-1990. Münster - Hamburg: LIT.

Václavek, Ludvík. 1966. Německý antifašista a český literát Vincy Schwarz. Šumperk: Vlastivědný ústav v Šumperku.

\section{Literature translated from Dutch in the Czech publishing house Družstevní práce during the Nazi occupation}

Czech translations. Dutch and Flemish literature. Publishing house Družstevní práce. Censorship. Archives.

This article uses the archives of the Czech publishing house Družstevní práce during World War II, which give insight into how certain works were selected as DP struggled to maintain its identity. Between the World Wars, DP published several Dutch and Flemish authors, but the number of translated works from Dutch grew considerably in the 1940s since Dutch-language literature was one of the few literatures allowed during the Nazi occupation. Despite the fact that the Nazi authorities exerted great pressure to publish Nazi-friendly literature, DP managed to avoid publishing such books by using officially acceptable Dutch, Flemish and Scandinavian works as a political compromise.

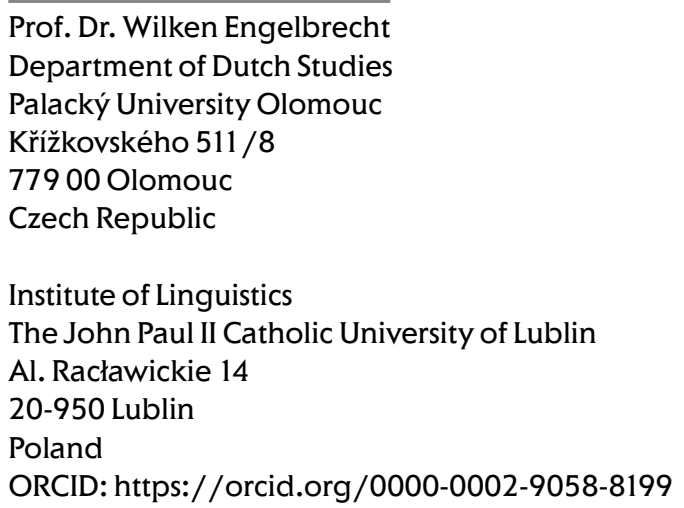

